\title{
The Relevance of Women's Social Issues Compared with Social Reality in Indonesia in the Short Story "Morgot" By Triyanto Triwikromo
}

\section{E. Chamalah¹, A. Nuryatin², S. A. Sayuti³, and I. Zulaeha ${ }^{4}$}

${ }^{1}$ Post-Graduate Students of Semarang State Universityand Lecturer of Sultan Agung Islamic University

${ }^{2}$ Professor of Humanities of Semarang State University

${ }^{3}$ Professor of Humanities of Yogyakarta State University

${ }^{4}$ Professor of Linguistics of Semarang State University

\section{Abstract}

One of the short story collections that discuss women's social issues is Malam Sepasang Lampion and Salah satu cerpen yang terdapat dalam kumpulan cerpen tersebut adalah

Corresponding Author:

E. Chamalah

chamalah@unissula.ac.id

Received: 6 April 2018

Accepted: 3 May 2018

Published: 26 July 2018

Publishing services provided by Knowledge E

(c) E. Chamalah et al. This article is distributed under the terms of the Creative Commons

Attribution License, which permits unrestricted use and redistribution provided that the original author and source are credited.

Selection and Peer-review under the responsibility of the ISLLE 2017 Conference Committee.

\section{G OPEN ACCESS}

cerpen Morgot. one of the stories in this collection is a short story entitled "Morgot." Penelitian ini bertujuan untuk (1) mendeskripsikan dan menjelaskan permasalahan sosial perempuan $k$ ategori kejahatan dalam cerpen $M$ orgot, (2) mendeskripsikan dan menjelaskan car a tokoh perempuan dalam cerpen $M$ orgot dalam menghadapi permasalahan sosial, (3) mendeskripsikan dan menjelaskan relevansi permasalahan sosial perempuan dalam kumpulan cerpen Morgot dengan realitas sosial. This study aims to describe and explain (1) women's social issues related to crime, (2) the way in which the female character deals' with social issues, and (3) the relevance of women's social issues compared with social reality in the short story "Morgot."

Keywords: relevance, social issues, the short story "Morgot"

\section{Introduction}

Women are often used as inspiration for the composition of literary works. An issue that is often discussed by authors in Indonesia and attracts the attention of society is the social issues surrounding women's lives. Women as members of society have two main functions, as individuals and as social creatures.

As social creatures, women interact a lot with the community and its environment. This interaction does not always run as expected and sometimes even ends with the development of an issue. A social conflict that occurs in women's lives is also known as "social conflict." This is in line with Waluya who explained that conflict 
is a social process that will inevitably occur in the midst of a dynamic society [1]. Conflict occurs because of differences or misunderstandings between individuals and community groups. Furthermore, Waluya explained that the social conflict in Indonesia is generally composed of two types, i.e. vertical conflicts, such as conflict among countries, or between workers and employers; and horizontal conflict, such as tribal, religious, or inter-community conflict [1].

Conflict is a social process that occurs in a dynamic society because of differences or misunderstandings between groups of people and/or individuals. Short story conflict means conflict between an individual and a community within the story. Conflict in a short story is always associated with social communities in the story. Women are social members of society, so the social issues of women in a short story are a social problem of a society in a short story that focuses on the social life of female figures.

Social issues occur when, in social life, one and other social elements do not perform their functions and roles in accordance with the prevailing social values and norms [2]. Every society, of course, has norms related to welfare, and physical and mental health, as well as adjustment of individuals or social groups. In regard to the common social issues of women, Abdullah stated that some of the issues faced by women, such as (1) violence, (2) rape and sexual harassment, (3) trafficking with motives such as being maids and prostitutes, and the end of all these actions is dead [3].

Social issues are the result of a mismatch between cultural elements and societies that endangers the lives of social groups or hampers the social will of the society, and often leads to social problems. Furthermore, Soekanto explained that social inequalities will soon cause social issues [4]. The presence of social issues is due to several factors. The first is economic factors, such as poverty, unemployment, etc. The second is biological factors related to physical disorders such as disease. The third is psychological factors derived from mental problems. The fourth is cultural factors, which raise issues related to divorce, crime, child delinquency, and racial and religious conflict.

Based on the above, it can be concluded that social issues occur because of the social lameness that occurs in the life of society, which, as a result, creates social problems caused by such issues.

The social problems of women found in many literary works are often used by poets and one of them is Triyanto Triwikromo. His short story collections that have been published include Rezim Seks (1987), Ragaula (2002), Sayap Anjing (2003), Anak Anak Mengasah Pisau (2004), Malam Sepasang Lampion (2004), Ular Dimangkuk Nabi (2009), and Celeng Satu Celeng Semua (2013). 
As an Indonesian poet, Triyanto Triwikromo has achieved many awards on several occasions, including from the Language Center in 2009, the best short story selection by Kompas in 2008, and in 2009 in Anugrah Sastra Pena Kencana.

Consequently, the writer is interested in analyzing one of his works. One of the short story collections that discusses the social issues of women is Malam Sepasang Lampion, and one of the stories contained in the collection is entitled "Morgot."

This study aims to describe and explain (1) women's social issues related to crime, (2) the way in which female characters deal with social issues, and (3) the relevance of women's social issues of compare with the social reality in "Morgot."

\section{Methods}

This study used a theoretical and methodological approach. The theoretical approach used was the approach of literary sociology and the mirror theory of lan Watt. The mirror concept in literature according to Watt is indicated from the formal facts that occur in nature in an accurate, absolute, and impersonal form [5]. Therefore, literature is said to be a mirror of nature. Furthermore, Damono explained that literary sociology expresses literature as a reflection of society. [6]

In addition to the theoretical approach, the methodological approach in the study included a qualitative descriptive approach. Qualitative descriptive research is based on existing facts or phenomena that are empirically alive in the storyteller, so what is produced or recorded is in the form of regular searches in exposure [7].

In addition, Moleong stated that qualitative research is a tradition in the social sciences that is fundamentally dependent on direct observation of humans in their real environment [8]. Based on the above, it can be concluded that this study is a literary sociology research that uses mirror theory and a qualitative descriptive analysis method. The focus of this study is a short story entitled "Morgot" taken from the short story collection Malam Sepasang Lampion by Triyanto Triwikromo [9].

The study design used involved the writer doing the following: (1) reading the story of "Morgot" heuristically and hermeneutically; (2) identifying "Morgot" as a short story in which to find the social issues of women in society through observation and literature; (3) classifying the data obtained by category; (4) setting these problems; (5) identifying the relevance of women's social issues compared with social reality.

The primary data in this study were extracts from the text of "Morgot" by Triyanto Triwikromo. The secondary data in this study were the observation of the social circumstances that support this study and documents obtained from newspapers. 
Furthermore, for the instrument, the writer used data cards. Each data card explained the focus of the research problem. Each data card contains a column number, data code, quotes, and information.

The data collection was done by heuristic and hermeneutic reading. Heuristic reading is reading based on language conventions, while hermeneutic reading is reading based on literary conventions [10]. Data analysis was conducted by using the dialectical analysis method. The first analysis carried out concerning the problems of women in the story of "Morgot." This was followed by analyzing surrounding communities by observing them and through a literature review with a focus on the social issues of women in society. After the text analysis, observation, and literature review were finished, the data were analyzed using an alternating system and the relevance of the data was figured out from the analysis results.

\section{Results}

\subsection{Criminal category of women's social problems in the short story of "Morgot"}

In the short story "Morgot," Morgot's unknown family background is described. He is a child who had been abandoned by her mother. This is shown in the following quotations:

"O Allah, whose baby have You sent to this hometown?" Uncle Arsyad exclaimed while reciting Subhanallah repeatedly.

"Ya, which virgin baby do you drift to this hometown full of bandits and prostitutes?" Aunt Basir exclaimed, howling.

Based on these quotes, it can be seen that Morgot was a child who was thrown away by his mother. Throwing away a child is a criminal act because a mother has cut the chance to live for the child. In this case, the mother had committed a crime against her own child.

The first factor that may lead to the problem of crime in the short story is the cultural factor. The Kedungombo community is said to be a village that is full of bandits and prostitutes. Therefore, the acts of killing and prostituting oneself have become the culture of the people there. So, it is strongly believed that Morgot is the son of a pregnant prostitute from an illicit relationship. To cover the shame, Morgot was eventually thrown out by his mother. The second factor is the economic factor. In 
the short story, it is clearly described that Kedungombo is a village with economic difficulties. This is shown in the following quotations:

"After he became a teenager, I found out that the baby had become a fighter from Kedungombo called Morgot. He was repeatedly bombed by the police for encouraging residents to refuse compensation for the land that had been used as a reservoir.".

"Please cross me in the middle of the dam, Nakmas. Please torment me with a bayonet or whatever. But please, Nakmas, do not separate me from the poor farmers who are about to be drowned."

Based on these two quotations, it can be seen that the people of Kedungombo were poor and oppressed, and some of them were only able to work as farmers. It can also be seen that the people of Kedungombo were in a difficult situation in terms of finding work because their only choice was to work as a farmer. Therefore, there were many criminal practices and women chose to work as prostitutes for a better life.

The mother figure was a part of Kedungombo society, hence the social context of the figure is included in the criterion of a society that is not rich and is poorly educated. In addition, the figure is also included in the criteria of a person who maintains her honor. The mother character belongs in the layer of society where she lived, which was an environment of bandits and prostitutes. Furthermore, the mother character belongs to the layers of society that maintain honor, which can be seen from her action when she threw away her child.

Based on the above, it can be concluded that the criminal acts of women throwing away children may be because of the influence of economic and cultural factors. Thus, the social contexts in the layers of society are not rich, poorly educated, and want to maintain honor.

\subsection{The way of women in Morgot short story to face problems}

In this short story, the female character is confronted with the main criminal problem, i.e. Morgot's mother. The way the character faces the problem can be described as follows.

Morgot's mother is a criminal character. She had dumped her son, i.e. Morgot when he was a baby, and threw him away in the river. Throwing out babies is a crime because the offender has cut the baby's chances of surviving. Then, the way the mother figure faced the problems that she had created was to remove all traces. This is illustrated 
by the fact that as an adult, Morgot was considered a snake child, because he did not know who his mother was and he had been found in the middle of the river surrounded by snakes. This is shown in the following quotations:

"I'm tired of explaining my origin." Morgot looked up at the hammering fan in the room. He gazed occasionally toward the three interiors which scattered strange questions.

"But you were really born from the womb of a snake, right?"

"I don't know."

This quotation shows that Morgot was considered to be a snake child because he was found in the river surrounded by snakes. When he grew up, he did not know who his mother was. This means that Morgot's mother faced a criminal problem because she had removed all traces and did not seek news of her child. Morgot's mother did this because there were supporting factors, namely economic and cultural.

\section{Conclusion}

From the above, it can be seen that Morgot's mother faced a criminal problem because she removed all traces and did not seek news of her child. What Morgot's mother did was not a good way to solve the problem. In this case, if Morgot's mother committed the crime for economic reasons, then her problem could be solved by giving her child to a social institution. If the crime was due to cultural factors, her problem could be solved by providing her with education or training in good exemplary culture. In the story of "Morgot," it is found that the social problems were mainly related to the life of female characters involved in crime. This includes an extremely important issue because, in the short story, the mother figure was willing to throw the child away and cut off a person's life and confined her child who had been pregnant. In relation to the problem, information was obtained from the newspaper that is relevant to the problems in Indonesia today, i.e. in the news from detiknews.com dated April 6, 2017, there was an article entitled "Sadistic Mother Throws Toddler into River in Bandung Regency" [11]. In the news, it was written that the victim (Fazar) died after being washed away by the Singaparaya river, Ciceret Residency, Ciapus Village, Banjaran District, Bandung Regency. According to the resident report, a body was found and a baby sling was also found not far from there, and then after it got crowded, the victim's mother admitted that it was her son. But the residents found the situation awkward because it was impossible that a toddler who could not walk could fall into the river 
and the mother's face showed no sadness at all. After the Banjaran police had taken the victim's mother in for questioning, it was true that the perpetrator claimed to wash away her child against the economic background. The mother had carried her son to a bridge, looked around her, and when it was safe had thrown her son into the river from the bridge. Then she watched as her son was washed away by the fast-running stream. After the poor child had been carried away by the river, she walked away from the location to Panenjoan Residency, Ciapus Village, Banjaran District. When she came across a banana tree, she threw away the cloth in which she had wrapped the child to remove all traces. Based on the above, it can be concluded that the women's problem in the story of "Morgot" is very relevant to the current social issues of women.

\section{Acknowledgement}

Author would like to thank Indonesian Language and Literature Education Study Program, Faculty of Teacher Training and Education, Sultan Agung Islamic University for facilitated this research.

\section{Conflict of Interest}

Author declare that there is no conflict of interest in this research.

\section{References}

[1] Waluya B: Sosiologi: Menyelami Fenomena Sosial di Masyarakat. Bandung: Setia Purna Inves; 2007.

[2] Setiadi EM, Kolip U: Pengantar Sosiologi: Pemahaman Fakta dan Gejala Permasalahan Sosial: Teori, Aplikasi, dan Pemecahannya. Jakarta: Kencana; 2011.

[3] Abdullah I: Konstruksi dan Reproduksi Kebudayaan. Yogyakarta: Pustaka Pelajar; 2009.

[4] Soekanto S: Sosiologi Suatu Pengantar. Jakarta: Raja Grafindo Persada; 2014.

[5] Watt IP: The Rise of The Novel: Studies in Defoe, Richardson, and Fielding. California: University of California Press; 2001.

[6] Damono SD: Pedoman Penelitian Sosiologi Sastra. Jakarta: Pusat Bahasa; 2002.

[7] Sudaryanto: Metode Linguistik: Ke arah Memahami Metode Linguistik. Yogyakarta: Gadjah Mada University Press; 1992. 
[8] Moleong LJ: Metodologi Penelitian Kualitatif. Bandung: PT Remaja Rosdakarya; 2008.

[9] Triwikromo T: Malam Sepasang Lampion. Jakarta: Kompas; 2014.

[10] Wicaksono A: Pengkajian Prosa Fiksi. Jogja: Penerbit Garudhawaca; 2014.

[11] Detiknews.com: Sadis, Ibu Buang Anak Balitanya ke Aliran Sungai di Kabupaten Bandung. April 6, 2017. Retrieved from: http://bit.ly/2FSZPRy 